\title{
Morphologic Features of Kapıdağ Peninsula and its Coasts (NW- Turkey) using by Remote Sensing and DTM
}

\author{
Cem Gazioğlu, ${ }^{1,2}$, Bedri Alpar ${ }^{3}$, Zeki Yaşar Yücel ${ }^{1}$, A. Edip Müftüoğlu ${ }^{1,2}$, Cem \\ Güneysu $^{3}$, T. Ahmet Ertek ${ }^{2,4}$, Volkan Demir ${ }^{1,2}$, Hakan Kaya ${ }^{2,5}$ \\ ${ }^{1}$ Istanbul University, Institute of Marine Sciences and Management, Department of Marine Environment, BERKARDA \\ Remote Sensing and GIS Laboratory, 34134 VEFA, FATIH, ISTANBUL-TR \\ ${ }^{2}$ Istanbul University, Faculty of Open and Distance Education, Associate Degree Program of GIS, FATIH, ISTANBUL-TR \\ ${ }^{3}$ Istanbul University, Institute of Marine Sciences and Management, Department of Marine Geology and Geophysics, \\ 34134 VEFA, FATIH, ISTANBUL-TR \\ ${ }^{4}$ Istanbul University, Faculty of Letters, Department of Geography, FATIH, ISTANBUL-TR \\ ${ }^{5}$ Beylikdüzü Municipality, BEYLIKDUZU, ISTANBUL-TR
}

Corresponding author. Tel: +902124400000

Received 22 July 2014

E-mail: cemga@istanbul.edu.tr

Accepted 28 Sept. 2014

\begin{abstract}
Although it is an inland sea, the Sea of Marmara and its surroundings have rather complex morphology due to the active tectonics of the North Anatolian Fault (NAF) zone in this region. The Kapıdağ Peninsula which is located at its southern coasts also represents a complex morphology. Macro morphologic units of Kapıdağ Peninsula are N-S trending deep valley systems, mountain areas and Belk1s isthmus. The most coastal area of peninsula has terraces, coastal plains and alluvial valley floors. These unique morphologic features can explain some parameters of active tectonics of the Sea of Marmara region. In order to investigate these geomorphologic features of the Kapıdağ peninsula in detail, some land observations, satellite data, Digital Terrain Models (DTMs which have been evaluated from topographic maps with a vertical precision of $\pm 3 \mathrm{~m}$ and cell size of $8 \mathrm{~m}$ ), Geographic Information Systems (GIS), traditional methods and some integrated techniques such as image processing were used.
\end{abstract}

Keywords: Kapıdağ, Sea of Marmara, NAFZ; Remote Sensing, LANDSAT, PCA, FCC, DTM.

\section{Introduction}

In these investigations, morphological features are described by both remote sensing and traditional technologies. Topographic analysis from maps and field observation are the most important elements in geomorphology. These observations and analysis can be improved by measuring, monitoring and analyzing the forms of terrain using by satellite data, DTMs and GIS. They are also able to explain and measure aspects of morphological features and processes (Walsh, et al., 1998). In this kind of studies, remote sensing can not only supply synoptic views but also it supplies measurements of the terrain and its attributes. Image processing systems are used for identified the morphological units by interpreting both satellite and DTM data together. Recently this technique opens new dimension on earth sciences. By using these techniques the positions, distributions and temporal and spatial relationships of geomorphologic units are explained easier than the traditional methods. Also, the patterns of landscape are emphasized by these techniques.

Satellite images have been one of the most effective data in earth sciences since the middle of the 1970's. Different satellite sensors operate in many part of portion of the electromagnetic spectrum which is able to explain different terrain features. Computer aid morphology contributes to various synoptic attempts at integrating land surface form with remotely sensed spectral and other important environmental data to facilitate a scale explanation of physical processes (Adediran, et al., 2004). In macro scales remote sensing supplies quality data and more detailed distributions in comparison with the traditional geomorphologic observations and surveys. In the same way it appears that the applying GIS 
techniques are beneficial for understanding the geomorphology. Basically, GIS can be defined as a computer system capable of assembling, storing, manipulating and displaying data which identified according to their locations.

GIS accommodates large varieties of spatial, spectral, temporal and attribute data which mostly generates from remote sensing techniques. The linkage between field works and new technologies can be supplied by using GIS media which provides managing and interpreting of these large data sets that might be in different format. For instance, the primary requirement for the source data is that the locations for the variables are known. Location may be annotated by $\mathrm{x}, \mathrm{y}$, and $\mathrm{z}$ coordinates of longitude, latitude, and elevation respectively. Any variable that can be located spatially can be fed into a GIS which joins different data sources within a spatial and thematic format. GIS analyzes and visualizes the spatial and temporal relationships among elements. It also measures aspects of geographic features which belong to tectonics. Satellite data, DTMs and GIS are the most acceptable and cost effective way to understand the geomorphologic features of terrain. Recently, satellite data, DTMs and GIS are used either independently or together in numerous applications (Adediran, et al., 2004; Gazioğlu, et al., 2004; Bishop, et al., 2003; Gökaşan, et al., 2003; Musial, et al., 2002; Gökaşan et al., 2002; Mayer, 2000; Wilson, et al., 2000; Novak and Soulakellis, 2000; McCullagh, 2000; Franklin, 1987; Ventura and Irwin, 2000).

\section{Principal Components Analysis (PCA)}

In advent image processing studies for earthsciences application extensive interband correlation is an obstacle frequently faced. PCA is often used as a procedure of data compression. Redundant data can be compacted into fewer bands using by PCA. Bands of PCA data are non-correlated, independent and more interpretable than source data. PCA involves the reorientation of axes of an input data set and crating output principal components data sets (Jansen, 1986). Images generated by remote sensing data from various bands often appear similar and essentially carry the same attributes (Lillesand and Kiefer, 1994). PCA is a method for transforming a set of correlated variables of images elements into a new set of uncorrelated variables of images elements. This procedure is a rotation of the original axes to new orientations that are orthogonal to each other and therefore there is no correlation between variables. PCA methods can reduce noise effects of the images. Another advantage of PCA is spectral various which are between materials can be more apparent in PCA images than in particular bands. Most of the variance in a multispectral data set is compressed into one PCA image is the most important advantage which makes this method essential (Novak and Soulakellis, 2000).

\section{False Color Composite (FCC)}

False Color Composites made by combining any three bands of images with some choice of color filters, generally blue, green, and red with image processing programs. FCC can be generated from the red, green and blue triplet which make up this rendition do not correspond to what human vision sees in the red, green, and blue electromagnetic spectrum.

\section{Digital Terrain Modelling or Models (DTMs)}

Digital Terrain Models (DTMs) are digital representations of the terrain. On the other hand, DTMs are convenient for representing the continuously varying terrain. They are well known and common data sources for terrain analysis and all spatial applications (Thompson, et al., 2001). These representations can be formed of grid, array, regular or irregular shapes. DTMs are commonly displayed in an image format. DTMs are used in many applications as geomorphologic, hydrological, meteorological and biological studies (Moore et al., 1991). DTMs, visualization and analysis play major role in understanding morphotectonic investigations and applications. Recently, DTMs permit scientist to visualize the topography and define topographic data structure in more detailed than the traditional (topographic) maps (Gazioğlu, 2001). Visualization of topographic features can be facilitated by image processing of digitized contour lines. Analyses of DTMs are an extension of image processing, all of these are designed to use topographic data to manipulate 
visualize and analyze the landscape in the context of surface processes. DTMs allow full data extraction from topographic maps and the automation of slope, aspect, contour, perspective views and pseudo 3D images (Bocco et al., 2001).

In this study, DTM data has $\pm 3 \mathrm{~m}$ vertical resolution and $8 \mathrm{~m}$ cell size from digitized contour lines using by 1:25 000 scale topographic maps. Accuracy of DTMs can be enriched by extreme terrain data. In processing, DTMs have been stored and used in real floating point form.

\section{Geology of Study Area}

The Sea of Marmara is an inland sea in NW Anatolia, which is located between the Aegean Sea in the south and the Black Sea in the north. It has a surface area of $11110 \mathrm{~km}^{2}$ (max. 280 $\mathrm{km}$. long, max. $80 \mathrm{~km}$. wide) and lies along east-west direction. It has broad shelf in the south (38\% proportion to total Marmara Sea area and $69 \%$ proportion to shelves) and narrower shelf in the north area $(17 \%$ proportion to total Marmara Sea area and 31\% proportion to shelves). Shelf area has a largest proportion among the other morphologic units in the Sea of Marmara (Gazioğlu, et al., 2002). The E-W-oriented basin chain between the Gulf of İzmit and the Ganos Mountain System is called here the "Marmara Trough". The four basins are separated by ridges constituted in the E-W direction of Marmara Trough which coincides with the northern branch of the North Anatolian Fault Zone (NAFZ) (Figure 1.a-e).

Since middle of the 1940's, numerous studies have been carried out to research the active tectonics of the Sea of Marmara and its surroundings. Firstly, Pinar (1942) proposed that a single E-W trending major fault transected in the Sea of Marmara, extending from the İzmit Bay in the east to the Ganos Mountain System in the west. Ketin (1948) identified the NAFZ along northern Anatolia as a right-lateral strike-slip fault. Some authors suggested that the northern branch of the NAFZ extended into the Sea of Marmara as a single shear zone (Pınar, 1942; Şengör, 1979; Şengör et al., 1985). In additionally some investigators supported that the area of the Sea of Marmara was cut by an E-W trending graben (Ketin, 1968; Cramplin and Evans, 1986; Smith, et al., 1995). Barka and Kadinsky-Cade (1988) discussed the segmentation and earthquake activity of the NAFZ in the Marmara Region. Some investigators agreed these suggestions (Armijo, et al., 2003; Armijo, et al., 1999; Wong, et al., 1995; Ergün and Özel., 1995;). and proposed a series of en-echelon strike-slip faults and pull-apart basins. These discussions engendered the Marmara phenomenon.

Recent data opened a new age to understand the phenomenon. The explanations of the NAFZ changed from the en-echelon strike-slip fault systems to an approximately $\mathrm{E}-\mathrm{W}$-trending single strike-slip fault zone (Okay et al., 1999; Okay et al., 2000; Aksu et al., 2000; Yaltırak, 2002; Gökaşan, et al., 2003). Gazioğlu (2001), İmren et al., (2001) and Le Pichon et al., (2001) named this fault zone as "Main Marmara Fault".

The NAFZ divided into branches toward the east of the Marmara Region. These branches have different kinematics and seismic features in the region. Most of studies in the Sea of Marmara and its surroundings are concentrated on the northern branch of NAFZ. Limited number of studies in the southern parts of the NAFZ is performed. The southern Marmara Region is placed in a tectonic basin which has been created by the development of the NAFZ since upper Pliocene. Paleogeographic evolution of the southern Marmara Region depends on sea level changes which caused by tectonic and glacio-eustatic movements.

The south Marmara region has a complex geology with a wide variety of metamorphic, magmatic and sedimentary rocks; their ages vary from Paleozoic to Paleogene (Aksoy, 1995). Kapıdağ peninsula which is the study area was shaped by NAFZ and its effects on the Marmara Region. Kapıdağ is located in the Sea of Marmara southern shelf $\left(27^{\circ} 40^{\prime}-28^{\circ} 02^{\prime} \mathrm{N}\right.$; $40^{\circ} 23^{\prime}-40^{\circ} 31^{\prime} \mathrm{E}$ ) (Figure 1d). It has important morphological and tectonic features which are able to explain NAFZ's mechanism in the southern Marmara Region. Kapıdağ Peninsula does not have only unique morphological features but also it has a unique geology according to the active tectonics of the 
Marmara Region. It has also unique magmatic features which is critical to assessing to magmatic history of its environment and western part of Anatolia Peninsula. It has a triangular and dome shape and peninsula connects the main continent with an isthmus. It has an approximate surface area of $300 \mathrm{~km}^{2}$ (Figure 1d). Wavy coasts, deep valley systems, existing terraces, hills which are 600-700 meters in height are the main morphological units of wide doomed shaped peninsula.

Southern part of the Marmara Sea is made up of different geologic units. Paleozoic-Paleocene metamorphic, magmatic, sedimentary rocks and Quaternary alluvium is dominant in geologic units of Kapıdağ (Erol, 1981). Paleocene granitoid units are also observed locally (Karacık, et al., 2008) (Figure 2).

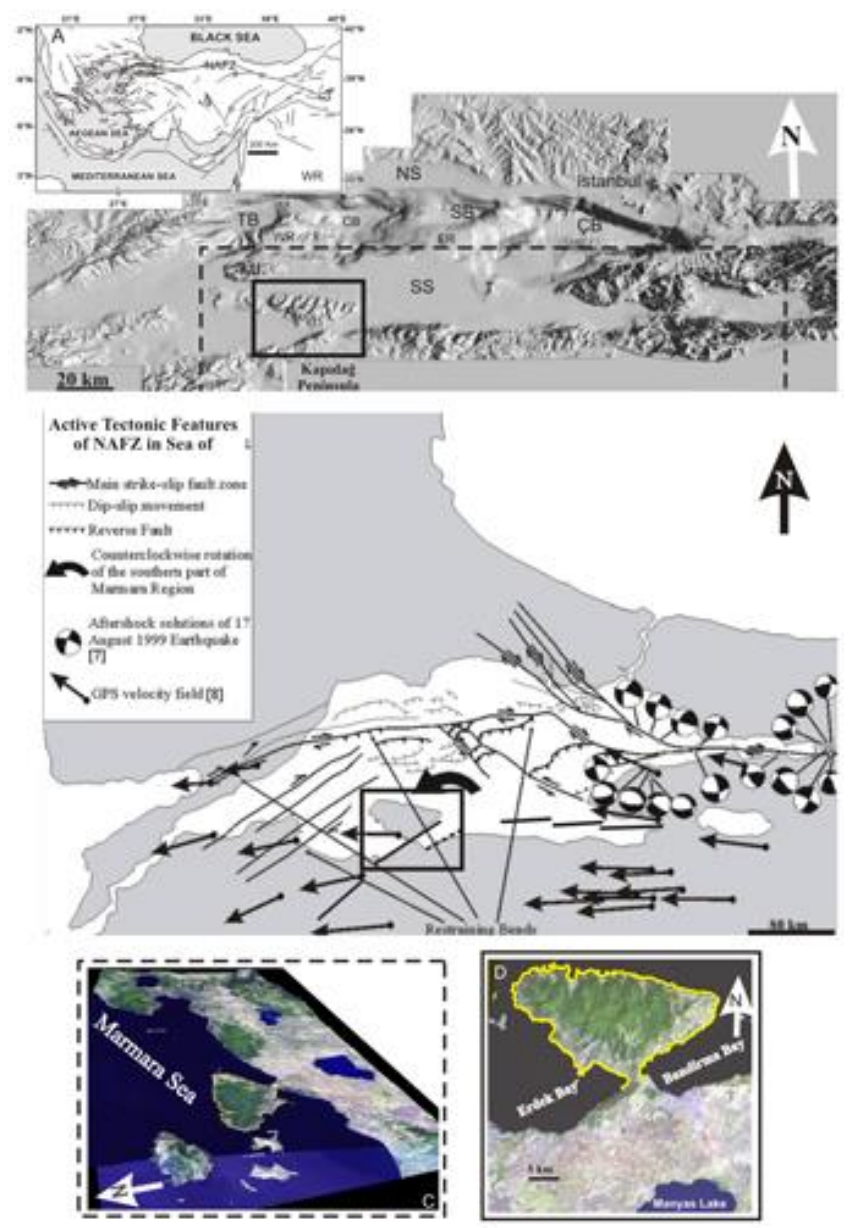

Fig 1. a. Location of Marmara Sea and general tectonic lineaments, b. Tectonic features of the Marmara Sea region as modified from (Örgülü and Aktar, 1999; Straub, 1996; Gökaşan, 2003). NAF: Northern Anatolian fault, c. Image Drape of Study Area, d. Study Area.

The Kapıdağ Peninsula is made up of crystallized metamorphic schist between two granite massifs in both the west and the east regions; gneiss and gneissic granites elongated as narrow bands along the northern coasts; and partly metamorphosed clayey schist and limestone units. The eastern granite massif placed in the east and southeast part of the peninsula is about $15 \mathrm{~km}$ long and made up of medium grained amphiboles and biotites. The western granite is made up of amphiboles and 


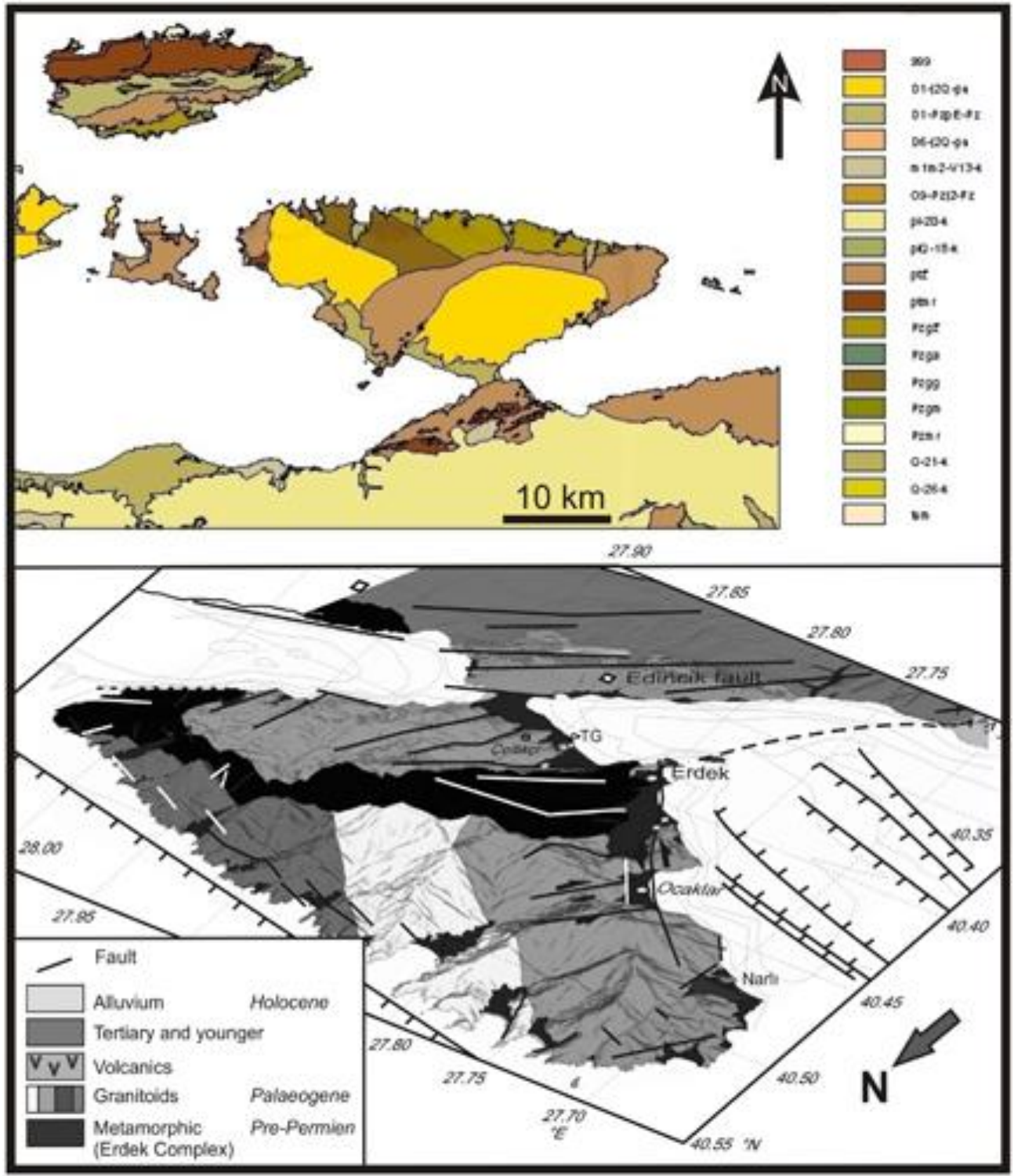

Fig 2. Image drape of Kapıdağ peninsula treated with a geological map compiled from Gazioğlu, et al. (2010).

\section{Conclusion}

Both regular and irregular drainage networks are situated in the peninsula. Regular rivers can be observed in the western side of the peninsula, while irregular river systems are dominant in the eastern side. Most of drainage networks are in dendritic patterns which are obtained from satellite data that is evaluated by both PCA methods and DTMs.
Dome shaped peninsula is cut by the N-S trending deep valleys mostly located in northern part (Figure 3). Mountainous areas are situated in the center of the Peninsula. Kesetepe $(782 \mathrm{~m})$ located in the central part is the highest point of the peninsula. On the basis of morphologic features and PCA interpretation of Landsat 5TM bands, the coasts can be divided into four main parts; southeast, north, southwest, south and the other important morphologic units are Belkıs and Erdek isthmus (Figure 3). 

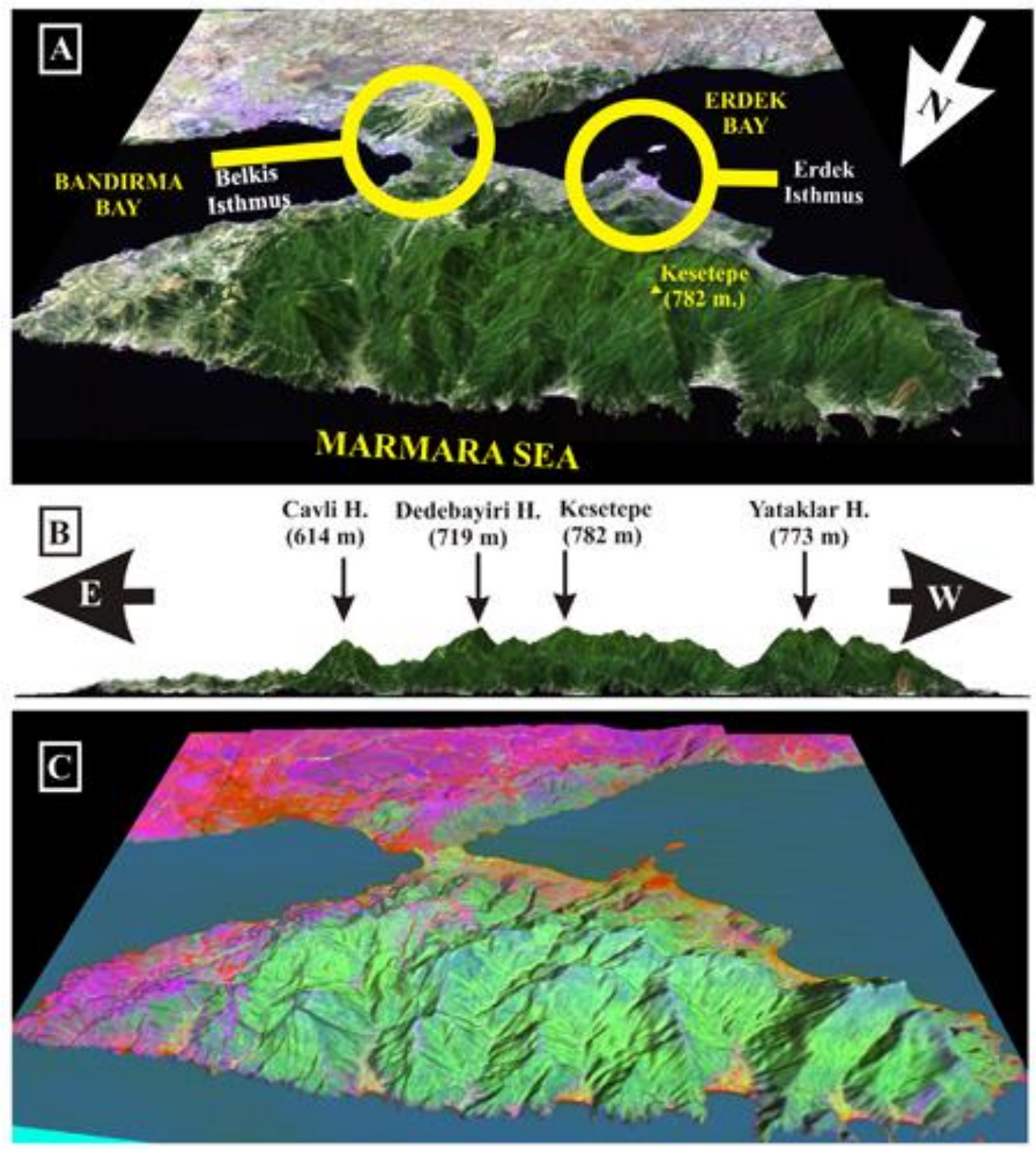

Fig. 3. a. 3D perspective view of Kapıdağ Peninsula (Natural Color composite Landsat TM 7, 5,3), b. perspective view of Kapıdağ Peninsula from north to south, 3D perspective view of Kapıdağ Peninsula (PCA).

Southeast coasts can be separated according to their unique features such as low-angle valleys with wide-floor and low cliffs, when compared with the other coasts of peninsula. The most important features of SE coasts are the wide plains at the base of the smoothly undulating mountains toward the north. These typical plains rise up northeastwardly, where the topography is undulates smoothly between two main valleys (Figure $4 a-b)$. The SE coasts lie parallel in the middle branch of the NAF which cut the Belkis isthmus in the south. There are no rivers to carry their load to the SE coasts.
Narrow inward-curving inlets in front of dry brooks are connected with small-scale capes. The valley-shaped underwater extensions in front of these inlets imply inundated rivers during post glacial age.

North Coasts; the valleys penetrate the steep northern coasts behind the coastline are deep and dense. Northern coasts which are open to physical effects such as dominant waves and winds have the highest scarps of the peninsula. C-shaped inlets, sandy beaches and coastal plains behind these inlets are main morphologic 
features. If compared with the other coasts, the inlets are smaller in size and in more convex shape. In addition the valleys behind these inlets are generally single (Figure 4c-d). Morphologic features of these Ria-type northern coasts change westwardly. C-shaped smaller inlets become bigger in size and wider inward, forming U-shape inlets.

This spatial metamorphosis of the morphology is attributed to the changing of lithology from metamorphic laminated rocks to gneiss-granite and granites (Figure 2). Detailed bathymetric studies and eroded material deposits on the sea floor imply that the northern coasts retreat rapidly. The deep valley system cutting through the northern coasts continue in the shelf area of the peninsula as well; highly possibly evolved during the last glacial age at the end of Quaternary. The alluvial fills in this valley system are due to both the sea level changes of the Sea of Marmara and the abundant material transported by winds and waves (Figures 3a-c, 4a-h).

West and Southwest coasts; there are no high scarps along the western coasts. Offshore, a group of islands which are separated by shallow waters less than $30 \mathrm{~m}$ are made up of the same lithological rocks as the Kapıdağ peninsula. This area is possibly evolved due to lacustrine erosion during sea-level lowstands. Three alluvial areas and 10-20 m high cliffs with 45$50^{\circ}$ slopes are dominant along the SW coasts. Some eroded and transported material is deposited in front of these cliffs which were reshaped by the harsh waves depending on their interior layering geometry (Figure 4a-b).

Southern Coasts and Belkıs isthmus; Southern coasts are bounded by a shallow sea and shaped by fine grained sands transported by the creeks from the north continent. In general, they resemble the SW coasts; however no higher cliffs take place in the area. Contrarily, wide, continuous and smoothly undulating alluvial plains are dominant (Figure 3a, 4e-h).

Belkıs Isthmus is placed on top of the highest part of an autochthonous ridge between the Bandirma Bay depression and west-dipping wide gutter. Two coastal spits, projecting from shore into the sea with the aid of the elongated points of the autochthonous ridge, connected the Kapıdag massive to the main land. The western spit evolved from NNE to SSE under the dominant oceanographic flow regime while the eastern one evolved from south to north. This narrow strip of land becomes narrower in northward. Some dead cliffs take place in its wider southern section. Ardel and İnandik (1957) claimed the swamp area in the central part as a remnant of a lagoon (Figure $3 \mathrm{a}, 4 \mathrm{e}-\mathrm{h}$ ).

In conclusion, two dominant coastal types are dominant along the modern coasts of the Kapıdağ Peninsula. While erosion is effective for $\mathrm{N}$ and SE coasts (Figure 4a-h, 5a-e), deposition is effective for $\mathrm{S}$ and $\mathrm{SW}$ coasts (Figure 4e-h). Plateau areas are situated in SW and NE of the peninsula. Coastal plains cover wider areas on SW and west coasts than on north and east coasts. The most important feature of northern coasts is the highest terrace on the Kapıdağ Peninsula (Figure 5a-e).

Sea terraces take place at 2-7, 7-8, 15-18, 20$25,45-50,60-65,70$ and $110 \mathrm{~m}$ elevations around the Kapıdağ Peninsula (Ertin, 1994). 2$7 \mathrm{~m}$ terraces refer to Nice phases. Most of other terraces refer to Thyrenien phases depending on the tectonic activity. Güneysu (1999) attributed $110 \mathrm{~m}$ terraces to Siciliyen phases. Existing of sea terraces along the eastern and western coasts at 45-50, 60-65, 80-85, $110 \mathrm{~m}$ altitudes imply that southern part of the peninsula was raised echelon.

In contrast there is no record of sea terraces (expects ones at 2-5 and 7-8 meters) along the northern coasts. Existing valley systems elongated into the sea may imply that W-E trending fault systems affected that part of the area before the Flandrian Transgression.

Fault related iron heads piled up along the northern coasts with different sizes indicate a sequence of regional uplifts (Figure 5d-e). The existence of suspended valleys either on the peninsula or on the narrow strip of the land which connects the massive to the land, is another important evidence of tectonic uplift (Figure5a-e). 


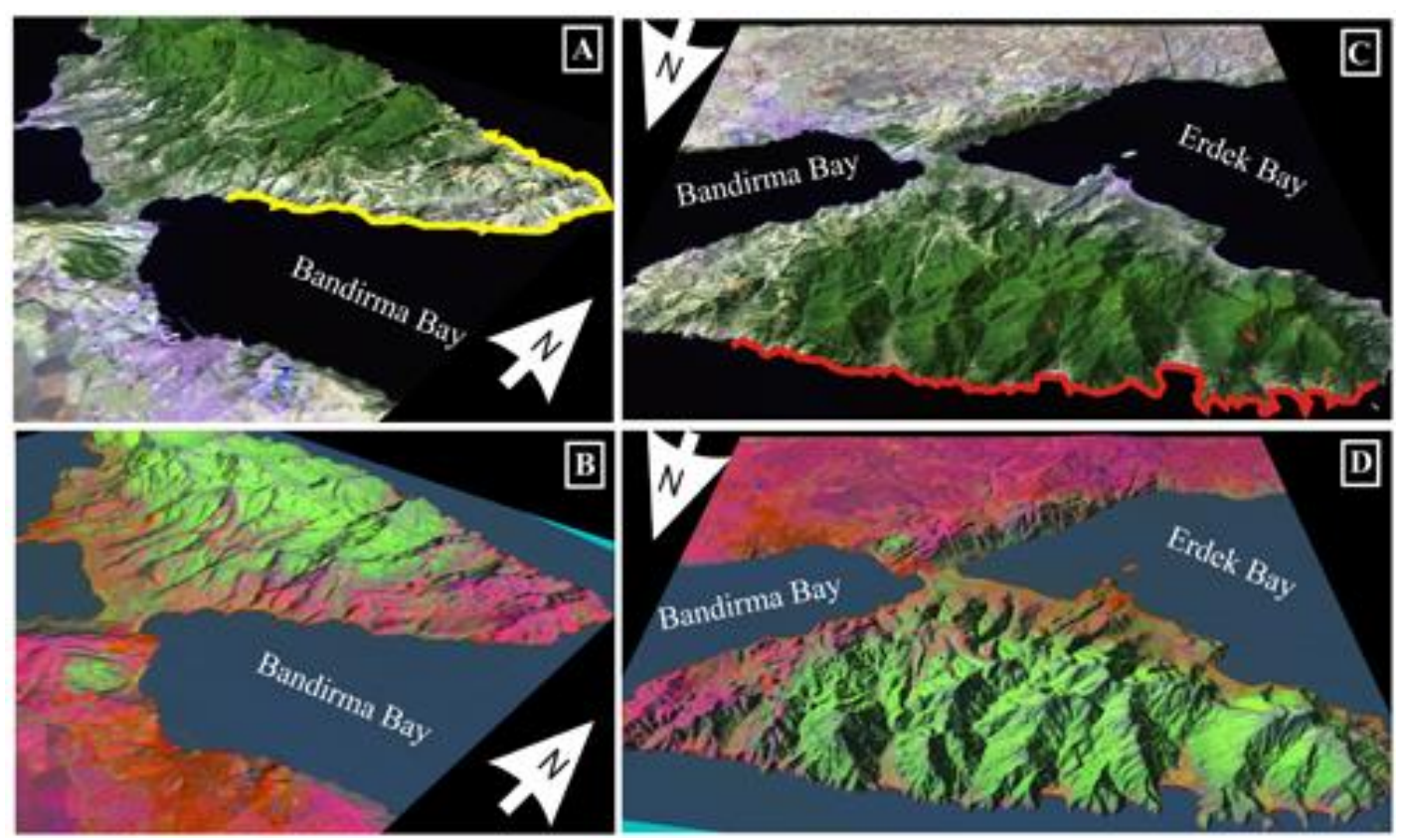

Fig 4. a. Eastern coasts of Kapıdağ Peninsula (Natural Color), b. Eastern coasts of Kapıdağ Peninsula (PCA), c. Northern coasts of Kapıdağ Peninsula (Natural Color), d. Northern coasts of Kapıdağ Peninsula (PCA).
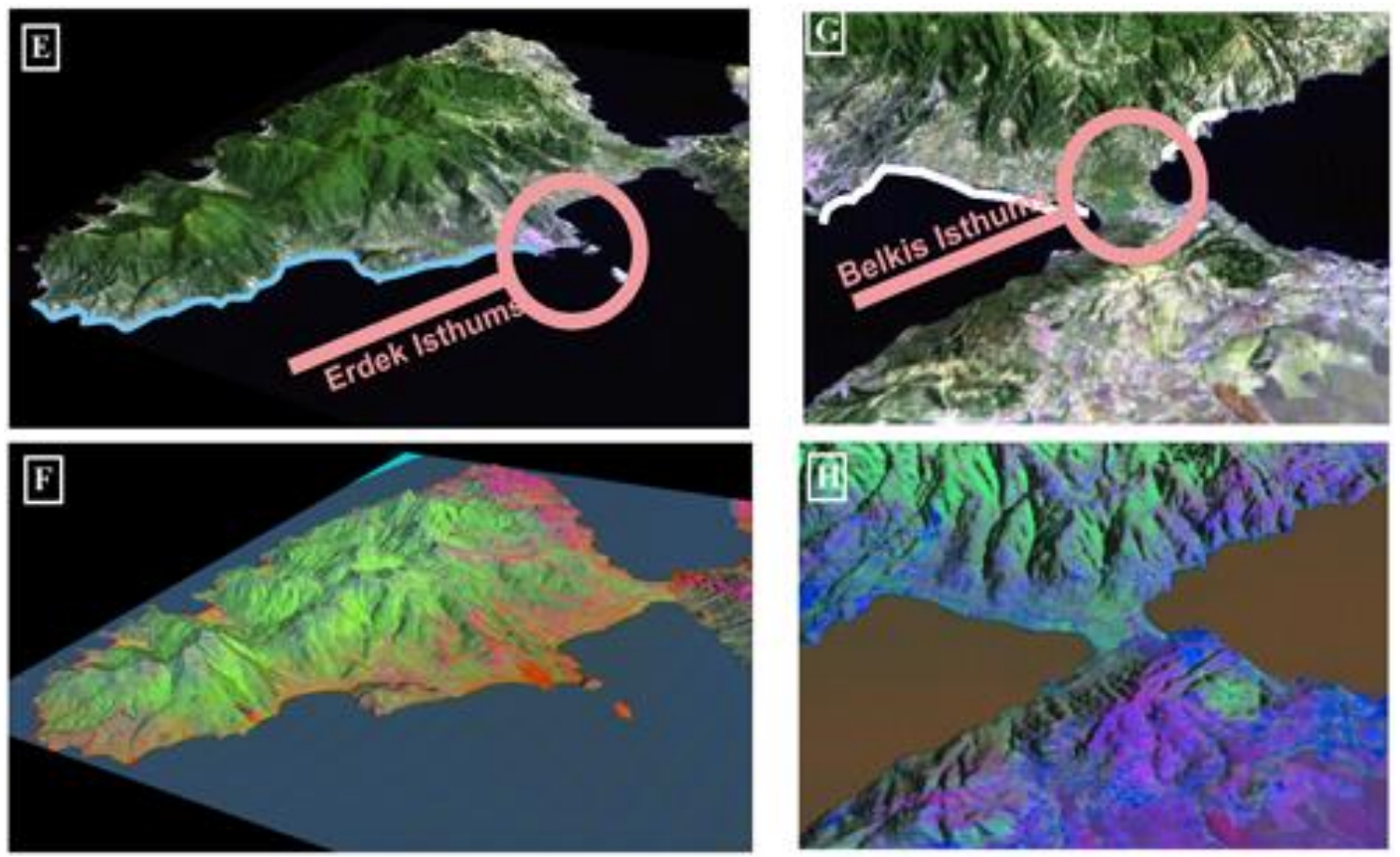

Fig. 4. e. Western coasts of Kapıdağ Peninsula and Erdek Isthmus (Natural Color), b. Western coasts of Kapıdağ Peninsula and Erdek Isthmus (PCA), c. SW coasts of Kapıdağ Peninsula and Belkıs Isthmus (Natural Color), d. SW coasts of Kapıdağ Peninsula and Belkıs Isthmus (PCA). 


\section{Geomorphology of Kapıdağ Peninsula by geomatic techniques}

The geomorphic appearance of the study area shows that the Kapıdag peninsula is governed by the active neotectonic regime. The level of marine terraces along the coastal area of the Kapıdağ peninsula, the suspended valleys at the northern and NE parts of the peninsula can be identified by PCA and DTMs. In addition, Güneysu (1999) suggests that some sudden slope changes in the underwater valleys and the Thyrenien terraces which are 20-50 m higher than their normal elevation exist around the Sea of Marmara. Negative Bouguer gravity anomalies with the above features, all indicate the uplift of the peninsula with vertical tectonic movements. The tectonic lineaments which had cut each other diagonally were as affective as deposition and erosion processes (Figure 5a-e).

According to (Aksoy, 1995; Ertin, 1994; Görür, et al., 1997), the peninsula is raised before Permiyen. The general shape of the peninsula, north coast structures and suspended valleys are the most important morphologic evidences of the uplift of the peninsula separately from the southern Sea of Marmara coasts. Around the Kapıdağ Peninsula, there are sea terraces in several elevation intervals $(2-7,7-8,15-18,20$ 25, 45-50, 60-65, 70 and $110 \mathrm{~m}$ ) (Ertin, 1994; Güneysu, 1999). 2-7m interval refers to Nice phases. Most of terraces which refer to Thyrenien phases depend on tectonic activity. Terraces of $110 \mathrm{~m}$ refer to the Siciliyen phases. As can be seen from the PCA and DTMs merged images, the levels of the terraces which are located at the SW and SE coasts are in agreement with each other contrary to other coastlines (Görür, et al., 1997). The iron faces with different sizes and elevations along the northern coasts show a gradual uplift of the northern part of the peninsula (Figure 5 a,d-e). The distribution of the highest topographic slopes also shows that the northern coasts (Figure 3c, $5 \mathrm{a}-\mathrm{c}$ ), which faces toward the most active northern branch of the NAF in the Sea of Marmara, have the highest uplift. Similarly, the trend of the older formations toward the NAF supports this sight as well.
Unique shape of the peninsula has been shaped by active tectonic elements of the Marmara Region. Although, shown big differences about coastal shape, the east, west north and south coast's connect the peninsula to continent which shows similar geomorphologic features. These differences and similarities are controlled by tectonic features of NAFZ.

For southern and SW coasts of the peninsula the deposition had been effective while erosion was dominant for the northern and SE coasts. The wavy shores of the northern peninsula are due to inundation of sea into the valleys during the last transgression. The promontories between the inlets retreated due to erosion while the valley beds were turned into alluvial areas by the lacustrine and marine depositional processes.

The lithology of the peninsula, active faults of the Sea of Marmara and its surroundings and related morphologic deformations occurred in the region is all responsible for the morphologic development of the Kapıdağ peninsula. This peninsula is considered to be evolved as a pressure ridge between the NE-SW trending right lateral strike-slip faults while the Erdek and Bandirma bays are considered as the pullapart basins between the strike-slip faults of the same system. Fluvial erosion and depositions, sea-level changes and wave dynamics are the most important agents and processes which concluded with the present geomorphologic appearance of the peninsula.

\section{Tectonic approach of Kapıdağ Peninsula}

When the Kapıdağ Peninsula is investigated by using DTMs the most remarkable morphologic agents are the NE-SW and NW-SE directional lineaments. The most evident of the mentioned lineaments is the one which forms the southern coast of the Kapıdağ Peninsula on NE-SW direction. This lineament that is numbered as 1 (Figure 6), bending slightly towards SW, follows the same direction and forms the coastal line in this region. This lineament is defined in many studies, like the one handled by Barka and Rellinger (1997), as a right lateral strait slipped fault which belongs to NAFZ.

For the rest of this lineament, which are located on NE-SW and NW-SE direction, they are 
thought to be shaped up by the rivers that are controlled by the tectonic lines in the region (Figure 6). When the lineament forms the Southern coast of the peninsula and the marine terraces are considered, the line read as reverse fault shifts towards the above lineaments can be an evident of the mentioned phenomena (Figure 6).

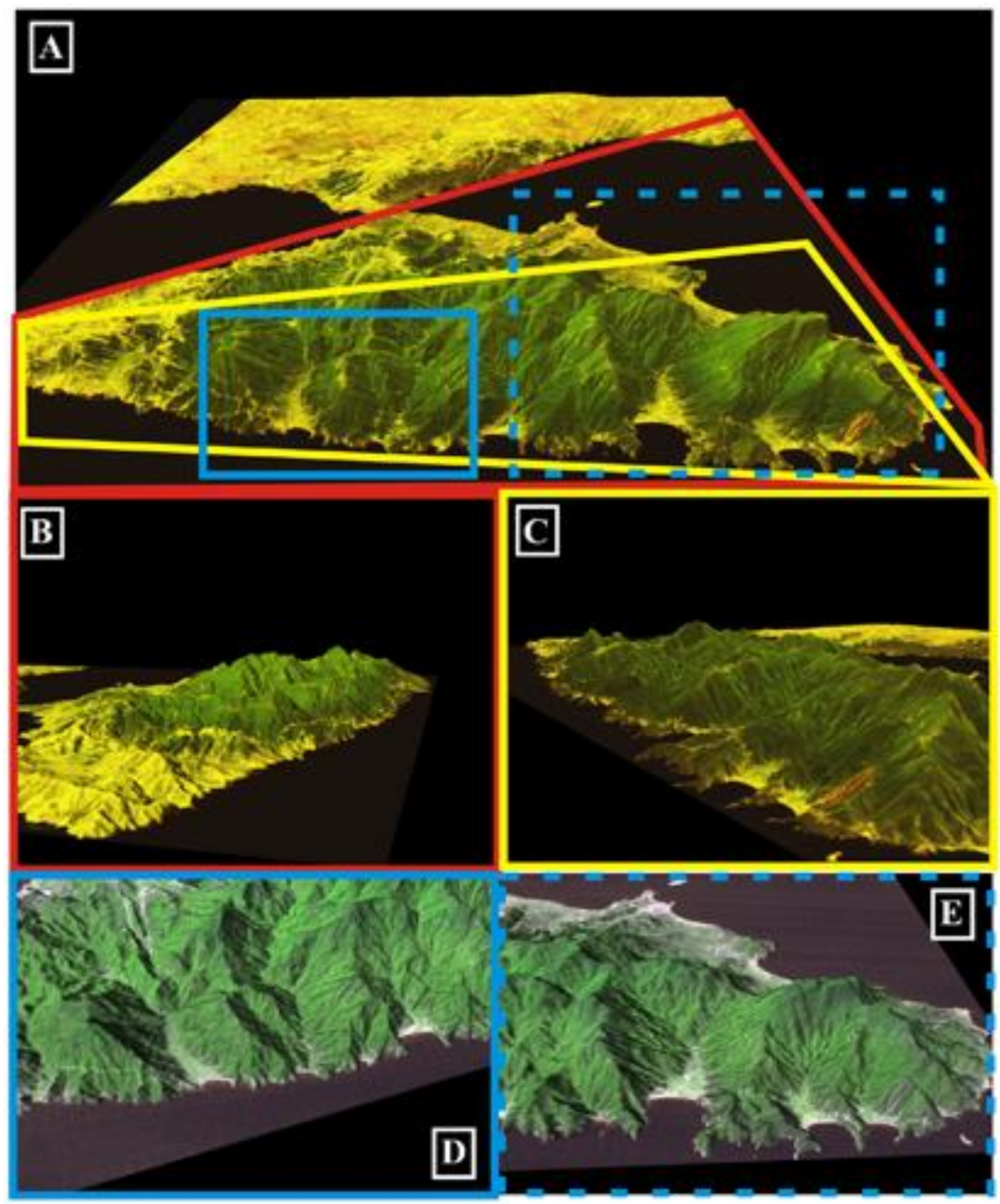

Fig. 5. 3D Perspective view of Kapıdağ Peninsula (Natural Composite Color), b. from NE to SW; c. from NW to SE ; d. U shaped coastal plains, e. C shaped coastal plains. 


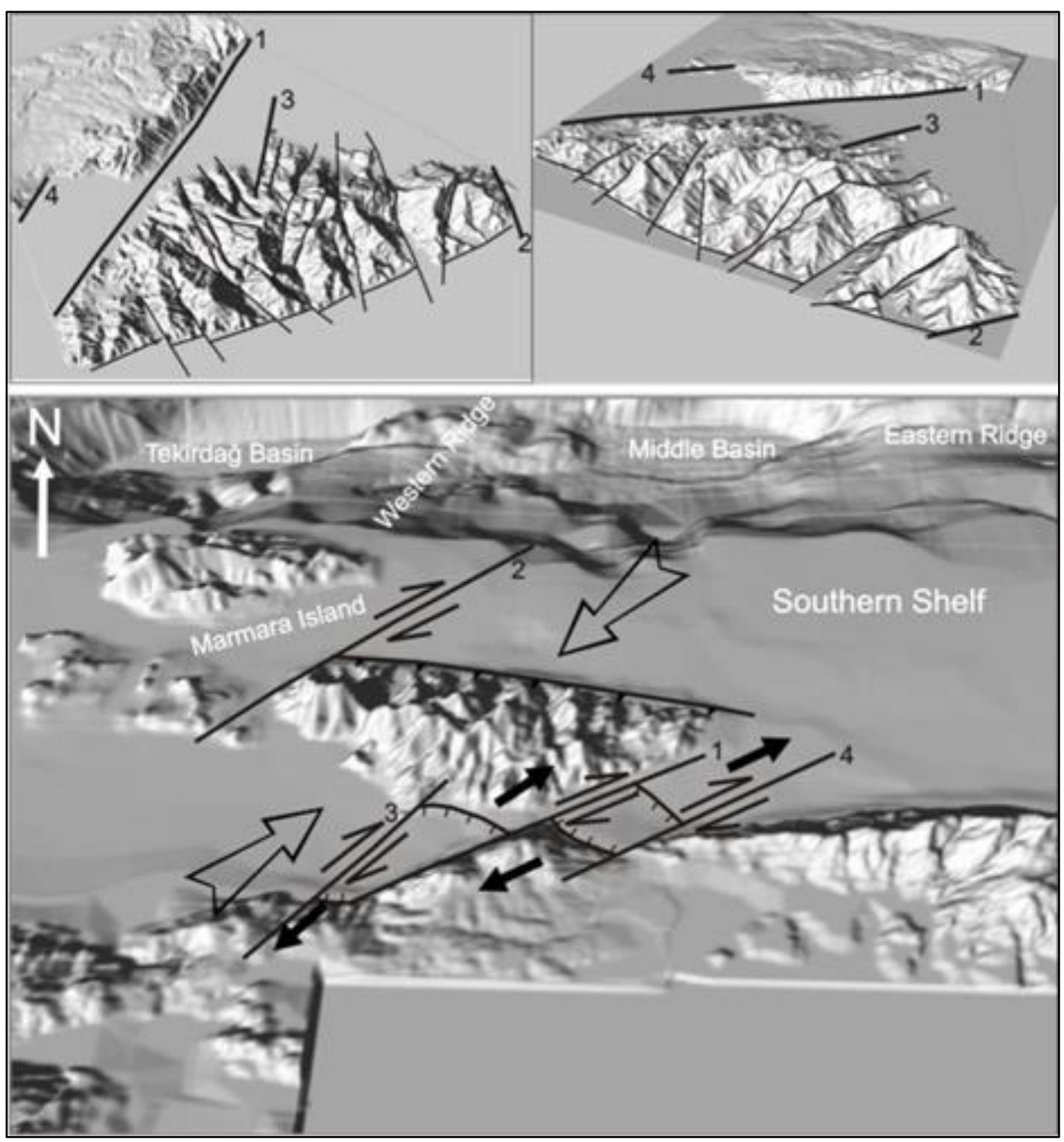

Fig. 6. Tectonic approach of Kapıdağ Peninsula

When it is compared with the relative matured plain located at the southern part of the Marmara Region with the upright sloped Marmara coasts near the Kapıdağ Peninsula (Figure 6), it suggests that the near past development of the region must be a sign of pressure. In addition to this, as the triangular shaped coasts of the Kapıdağ Peninsula and the locations of the peninsula, Erdek and Bandirma Bays are considered with the NE-SW elongated strike-slip fault, suggestion of a model where more local stressed and strained tectonic

structure is dominant comes up for such a morphologic formation.

According to this model, different right lateral faults must be parallel with the fault 1 (Figure6). Thus, Kapıdağ Peninsula must have developed as a pressure ridge between faults 1 and 2 which is the component of the system that borders the peninsula at the northwest part (Figure6). By means of this development model the existence of marine terraces determined at the Kapıdağ Peninsula, quite high elevation of 
the peninsula and the existence of NAFZ can be explained together.

When the right lateral strike-slipped fault that are thought to form the other lineaments in NESW direction faults 3-4, also as fault 1 are considered it seems to be possible that the Erdek and Bandirma Bays which lie southwest and southeast of the Kapıdağ Peninsula respectively are shaped as pull-apart catchments one each (Figure 6.).

By the help of this study an approach to the morphotectonic properties of the Kapıdag Peninsula is developed under the light of the recent studies about the NAFZ and DTMs. Thus the Kapıdağ Peninsula and its surroundings are determined as a pressure ridge that grown up between the NE-SW directional right lateral strike-slip fault of NAFZ and the Erdek and the Bandırma Bays are interpreted as pull-apart catchments shaped between the strike-slipped faults of the same system. The assumption that the Kapıdağ Peninsula formed between the NE-SW directional right lateral faults forms the basis of this model.

In this study, it can be obviously seen that topographic analysis from maps and field observation are both important elements of geomorphologic mapping which still holds as a valuable research tool in geomorphologic investigations. But remote sensing and DTMs interpretation opens new dimensions and additionally DTMs are the straightforward identification of surface features and characterization in geomorphology (Figure 7ad), especially, investigation of associated with tectonics (Figure 6). The accuracy of DTMs may be critical when the DTMs data are used for prediction of spatial distribution of morphologic features, hydrological and biological properties and environmental modeling. Other important purpose of DTMs in geomorphology is the straightforward identification of surface features and characterization.

\section{Acknowledgements}

Funding was allocated by the research fund of Istanbul University; under Project No: BYP1073/031297 allocated to C. Güneysu and Project No: BYP-218/04062003 and UDP236/10032004 allocated to C. Gazioğlu. 


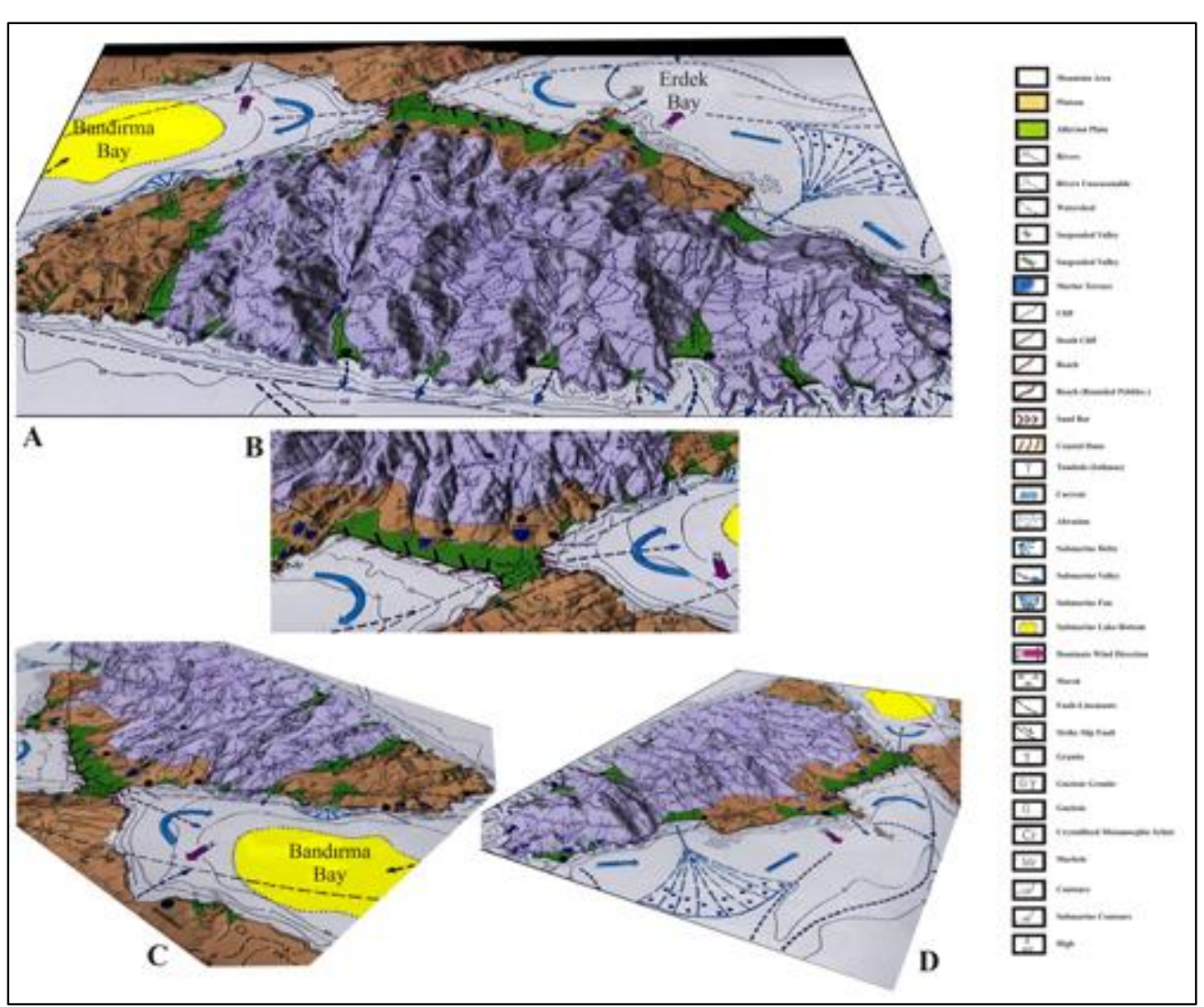

Fig 7. a. 3D perspective view of Kapıdağ Peninsula morphological units, b. Belkis Isthmus, c. from SE to NW, d. from SW to NE (Draped from Güneysu, 1999).

\section{References}

Adediran, A.O., Parcharidis, I., Poscolieri, M., Pavlopoulos, K. Computer assisted discrimination of morphological units on north central Crete (Greece) by applying multivariate statistics to local relief gradients. Geomorphology, 2004, 58, 357370.

Aksoy, R. Marmara Adası ve Kapıdağ Yarımadası'nın Stratigrafisi (Stratigraphy of Marmara Island and Kapıdag Peninsula). Türkiye Petrol Jeologları Derneği Bülteni, 1995, 7(1), 3-49.

Aksu, AE., Calon, TJ. And Hicott, RN. Anatomy of the North Anatolian Fault Zone in the Marmara Sea, western Turkey: extensional basins above a continental transform. GSA Today, 2000, 10(6): 3-7.
Alpar, B., Yaltırak, C. Characteristic features of the North Anatolian Fault in the eastern Marmara region and its tectonic evolution. Marine Geology, 2002.. 190, 329-350.

Ardel, A., Inadık, H. Kapıdağ Yarımadası Berzahı (Belkis Tombolosu). İstanbul Üniversitesi, Coğrafya Enstitüsü Dergisi, 1957, 4(8), 65-66.

Armijo, R., Meyer, B., Hubert, A., Barka, A. Westward propagation of the North Anatolian Fault into the northern Aegean: timing and kinematics. Geology, 1999, 27, 267-270.

Armijo, R., Meyer, B., Navarro, S., King, G., Barka, A. Asymmetric slip partitioning in the Sea of Marmara pull-apart: a clue to propagation processes of North Anatolian Fault? Terra Nova, 2003, 14(2), 80-86. 
Barka A. and Rellinger, R., Active tectonics of the eastern Mediterranean region: deduced from GPS, neotectonic and seismicity data. Ann Geofisica 1997, 11:587-610.

Barka, A., Kadinsky-Cade, K. Strike-slip fault geometry in Turkey and its influence on earthquake activity. Tectonics, 1988, 7, 663-684.

Bishop, M.P., Shroder, J.F., Colby, J.D. Remote Sensing and geomorphometry for studying relief production in high mountains. Geomorphometry, 2003, 55, 345-361.

Bocco, G., Mendoza, M., Velazquez, A. Remote Sensing and GIS- based regional geomorphological mapping- a tool for landuse planning in developing countries. Geomorphology, 2001, 39, 211-219.

Crampin S., Evans, R. Neotectonics of the Marmara Sea region of Turkey. Journal of the Geological Society (London), 1986. 143, 343-348.

Ergün, M., Özel, E., Structural relationship between the Sea of Marmara basin and the North Anatolian Fault. Terra Nova, 1995, 7, :278-288.

Erol, O. Neotectonic and Geomorphologic Evolution of Turkey. Zeitschrift für Geomorphologie, 1981, 40, 193-211.

Erol, O. Türkiye Jeomorfoloji Haritası (1:2,000,000). MTA Enstitüsü Yayınları, 1982, Ankara.

Ertin, G. Kapıdağ Yarımadasının coğrafi etüdü. İstanbul Üniversitesi, Coğrafya Enstitüsü Dergisi, 1994, 2: 283-314.

Franklin, S.E. Geomorphometric processing of digital elevation models. Computers and Geosciences, 1987, 13(6), 603-609.

Gazioğlu, C. Investigation of Geomorphology of Marmara Sea Bottom and surrounding area by Geomatic. Istanbul University, Institute of Marine Sciences and Management PhD. Thesis (No: 97), 2001, p.121.

Gazioğlu, C., Burak, Z.S., Alpar, B., Türker, A., Barut, F.I. Foreseeable impacts of the sea-level rise on the Southern coasts of the Marmara Sea (Turkey), Water Policy, 2010, 12, 932-943.
Gazioğlu, C., Gökaşan, E., Algan, O., Yücel, Z.Y., Tok, B., Doğan, E. Morphologic features of the Marmara Sea from multibeam data. Marine Geology, 2002, 190, 397-420.

Gazioğlu, C., Yücel, Z.Y., Doğan, E. Morphological Features of Major Submarine Landslides by multi beam data. Journal of Coastal Research, 2004, 21(4), 664-673.

Gökaşan, E., Gazioğlu, C., Alpar, B., Yücel, Z.Y., Ersoy, Ş., Gündoğdu, O., Yaltirak, C. AND Tok, B. Evidence of NW extension of the North Anatolian Fault Zone in the Marmara Sea: a new interpretation of the Marmara Sea (Izmit) Earthquake on 17th August 1999. Geo Marine Letters, 2002, 21, 183-199.

Gökaşan, E., Ustaömer, T., Gazioğlu, C., Yücel, Z.Y., Öztürk, K., Tur, H., Ecevitoğlu, B., Tok. B. Morpho-tectonic evolution of the Marmara Sea inferred from multi-beam bathymetric and seismic data. Geo-Marine Letters, 2003, 23 (1), 19-33.

Görür, N., Çağatay, N., Sakınç, M., Sümengen, M., Şentürk, K., Yaltirak, C., Tchepalyga, A. Origin of the Sea of Marmara as deduced from Neogene to Quaternary Paleogeograophic Evolution of its Frame, International Geology Rewiev, V.H. Winston and Son Inc. 1997, 39, 342-352.

Güneysu, C. Kapıdağ Yarımadası Kıyılarının (Güney Marmara) Jeomorfolojisi. Istanbul University, Project of Research Foundation, Number: 1073/031297, 1999.

Imren, C., Le Pichon, X., Rangin, C., Demirbağ, E., Ecevitoğlu, B., Görür, N. The North Anatolian Fault within the Sea of Marmara: a new evaluation based on multichannel seismic and multi-beam data. Earth Planet Science Letters, 2001, 186, 143-158.

Jansen, J.R. Introductory Digital Image Processing. Englewood Cliffs, New Jersey: Prentice-Hall, 1986.

Karacık, Z., Yılmaz, Y., Pearce, J.A. and Ece, Ö.I. Petrochemistry of the South Marmara granitoids, northewest Anatolia, Turkey, Int. J. earh Sci. (Geol Rundsch), 2008, 97:11811200 
Ketin, I. Relations between general tectonic features and the main earthquake regions in Turkey. MTA Bulletin, 1968, 71, 129-134.

Ketin, İ. Über die tektonisch-mechanischen Folgerungen aus der grossen anatolischen Erdbeben des letzten Dezenniums. Geologische Rundschau, 1948, 36, 77-83.

Kuşcu, İ., Okamura, M., Matsuoka, H., Awata, Y. Active faults in the Gulf of Izmit on the North Anatolian Fault, NW Turkey: a high resolution shallow seismic study. Marine Geology, 2002, 190: 421-433.

Le Pichon, X., Şengör, AMC., Demirbağ, E., Rangin C., Imren, C., Armijo, R., Görür, N., Çağatay, N., Mercier De Lepinay, B., Meyer, B., Saatçiler, R., Tok B. The active main Marmara Fault. Earth Planet Science Letters, 2001, 192, 595-616

Lillesand, T.M., Kiefer, R.W. Remote Sensing and Image Interpretation 3rd Edition. Wiley Pub., 1994, p. 750.

Mayer, L. Application of digital Terrain Models to macroscale tectonic geomorphology. Geomorphology and Global Tectonics (Summerfield, M.A.), J. Wiley Pub., 2000, pp. 15-27.

McCullagh, M.J. Quality, Use and Visualization in Terrain Modeling. Landform Monitoring, modeling and Analysis (Eds.: Lane, S.N., Richards, K.S. and Chandler, J.H. ) Wiley Pub. 2000, pp.95-139.

Moore, I.D., Grayson, R.G. Landson, A.R. Digital Terrain Modeling: a review of hydrological, geomorphological and biological applications. Hydrological Processes, 1991, 5. pp. 3-30.

Musial, W.W., Lewisnski, ST., Zagajewski, B. Geomorphological Map (Tykocin Sheet). Methodology. Observing our Env. From Space: New solution for a new millennium (Ed. Gérard Bégni), 2002, ISBN 905809 254 2. 385-390p.

Novak, I.D., Soulakellis, N. Identifying Geomorphic Features using LANDSAT 5TM data processing techniques on Lesvos, Greece. Geomorphology, 2000, 34, 101109.

Okay, A., Demirbağ, E., Kurt, H., Okay, N. Kuşçu, İ. An active, deep marine strike-slip basin along the North Anatolian fault in Turkey. Tectonics, 1999, 18(1), 129-147
Okay, A., Kaşlilar-Özcan, A., Imren, C.,, Boztepe-Güney, A., Demirbağ, E., Kuşçu, İ.. Active faults and evolving strike-slip basins in the Marmara Sea, northwest Turkey: a multichannel seismic reflection study. Tectonophysics, 2000, 321, 189-21.

Örgülü, G., Aktar, M., Regional moment tensor inversion for strong aftershocks of the August 17, 1999, İzmit Earthquake $(\mathrm{Mw}=7.4)$, Geophysical Research Letters., 2001, 28(2), 371-374.

Pınar, N. Géologie et météorologe sismiques du bassin de la mer de Marmara. İstanbul Üniversitesi, Fen Fakültesi Mecmuası, 1942, VII(3/4), 121-182.

Şengör, AMC. The North Anatolian Transform Fault; its age offset and tectonic significance. Journal of the Geological Society (London), 1979, 136, 269-282.

Şengör, AMC., Görür, N., Şaroğlu, F. Strikeslip faulting and related basin formation in zones of tectonic escape: Turkey a case study. Strike-slip Deformation, basin Formation, and Sedimentation (Eds: Biddle, K.T. and Christie-Blick, N.) Soc. Econ. Paleont. Min. Spec. Pub. 1985, 37 (in honor of J.C. Crowell), 227-264.

Smith AD, Taymaz T, Oktay F, Yüce H, Alpar B, Başaran H, Jackson J.A, Kar S., Şimşek M. High-resolution seismic profiling in the Sea of Marmara (northwest Turkey): Late Quaternary sedimentation and sea-level changes. Geology Society of American Bulletin, 1995, 107, 923-936.

Straub, C., Recent crustal deformation and strain accumulation in the Marmara Sea region, NW Anatolia, inferred from GPS measurements, $\mathrm{PhD}$. Thesis, Institut für Geodesie und Photogrammetrie, Mitteilungen Nr. 58, Zürich, 1996.

Thompson JA, Bell JC., Butler CA. Digital elevation model resolution: effects on terrain attribute calculation and quantitative soil-landscape modeling, Geoderma, 2001, 100 (1-2), 67-89.

Ventura, S.J., Irwin, B.J. Automated landform classification methods for soil landscape studies. Terrain Analysis: Principles and Applications (Eds:. Wilson, J.P., Gallant, J.C.) Wiley, New York, 2000, pp. 267-290. 
Walsh, S.J., Butler, D.R, Malanson, G.P. An overview of scale, pattern, process relationship in geomorphology: a remote sensing and GIS perspective. Geomorphology, 1998, 21, 183-205.

Welch, R Usery, L.E. Cartographic Accuracy of Landsat MSS and TM Image Data, IEEE, Transaction on Geoscience and Remote Sensing, 1984, GE-22, 3.

Wilson, J.P., Gallant, J.C. Digital Terrain Analysis. Terrain Analysis: Principles and Applications (Eds:. Wilson, J.P., Gallant, J.C.) Wiley, New York, 2000, pp. Wiley, New York, 1-27.
Wong, HK., Lüdmann, T., Uluğ, A., Görür, N. The Sea of Marmara: a plate boundary sea in an escape tectonic regime. Tectonophysics, 1995, 244, 231-250.

Yaltırak, C. Tectonic evolution of the Marmara Sea and its surroundings. Marine Geology, 2002, 190(1-2), 493-529. 